\title{
First record of the northern bald ibis Geronticus eremita (Linnaeus, 1758) in Bulgaria
}

\author{
Zlatozar Boev ${ }^{1}$, Gradimir Gradev ${ }^{2}$, Hristina Klisurova ${ }^{3}$, Ivaylo Klisurov ${ }^{4}$, Rusko Petrov $^{5}$
}

1 National Museum of Natural History, Bulgarian Academy of Sciences, 1 Tsar Osvoboditel Blvd, 1000 Sofia, Bulgaria, boev@nmnhs.com, zlatozarboev@gmail.com

2 Wildlife Rehabilitation and Breeding Center, Green Balkans - Stara Zagora, 9 Stara Planina Street, Stara Zagora 6000, Bulgaria, ggradev@greenbalkans.org

3 Wildlife Rehabilitation and Breeding Center, Green Balkans - Stara Zagora, 9 Stara Planina Street, Stara Zagora 6000, Bulgaria, hhristova@greenbalkans.org

4 Wildlife Rehabilitation and Breeding Center, Green Balkans - Stara Zagora, 9 Stara Planina Street, Stara Zagora 6000, Bulgaria, hhristova@greenbalkans.org

5 Wildlife Rehabilitation and Breeding Center, Green Balkans - Stara Zagora, 9 Stara Planina Street, Stara Zagora 6000, Bulgaria, rpetrov@greenbalkans.org

Abstract: The paper reports on the first record of Geronticus eremita in Bulgaria (13-16 January 2019; town of Karlovo), a specimen released from the captive population in Rosegg Tierpark, Austria and caught alive in the town of Karlovo (CS Bulgaria). Regardless of the attempts to be rescued a few days later, it died.

Keywords: avian rarities, Balkan avifauna, birds of Bulgaria, bird reintroduction, endangered birds

\section{Introduction}

At present, the northern bald ibis, Geronticus eremita (Linnaeus, 1758), is an Endangered species, with estimated only 200-249 birds still surviving (BirdLife International, 2018). After other data, the population in Morocco in 2016 numbered ca. 601 birds (Aourir et al., 2017). In addition, a semi-wild population of 200 ibises is sustained in south-eastern Turkey (Schwägerl, 2018).

The northern bald ibis is one of the four avian species disappeared from the European bird fauna in the historic period (Finlayson, 2011). Along with the great auk (Pinguinus impennis), a globally extinct species since 1852 (del Hoyo \& Collar, 2014), the black francolin (Francolinus francolinus (Linnaeus, 1766)), which survived on some Aegean Islands until the middle of $19^{\text {th }}$ century (Harrison, 1982), the slenderbilled curlew (Numenius tenuirostris Vieillot, 1817), disappeared in Europe in the middle of $20^{\text {th }}$ century (del Hoyo \& Collar, 2014) and the native nominate race Ph. c. colchicus Linnaeus, 1758 of the common pheasant, disappeared ca. 1990s (Boev et al., 2007), the northern bald ibis was widely spread in the region of the Alps and southern peninsulas of Europe (Boev, 1992, 1998).

According to Tyrberg (1998), the fossil record of G. eremita is dated to the Late Pliocene / Early Pleistocene from the Iberian Peninsula (Early Pleistocene) and Italy (Middle Pleistocene). In addition, the species was found in the Holocene deposits of southern France (Mourer-Chauviré, 2006).

\section{Past distribution of the bald ibis on the Balkan Peninsula}

Although no evidences for the past distribution of $G$. eremita are known from the present territory of Bulgaria, the fossil record confirms the former (Late 
Pleistocene) occurrence of the bald ibises (genus Geronticus) in the country ca. 1.85 Mya (Boev, 1998, 2000).

Desfayes (1987) presents evidences for the former occurrence of $G$. eremita in the region of the Lake Stymphalus in the north-eastern Peloponnese in southern Greece, while Perco \& Tout (2001) assume the species occurred in the Upper Adriatic Region until the $19^{\text {th }}$ century.

\section{Specimens of the northern bald ibis in the Vertebrate Animals Department of the National Museum of Natural History, BAS}

At present, two dry full-body mounted preserves are kept in the collections of the Vertebrate Animals Department of the National Museum of Natural History, BAS. Both have been obtained after 1907 (but no data on specimens of $G$. eremita were included in the collections catalogue of Gretzer (1907)). Probably they were collected from one of the Syrian colonies and were kept at the private zoo of the Tsar Ferdinand I in Sofia: (1) NMNHS 2147 ad. male, died 16 July 1911; (2) NMNHS 2148 ad. female, died 30 August 1911 (Fig. 1) (Boev, 2003).

\section{The 2019 record of the northern bald ibis in Bulgaria}

The first live individual of G. eremita in Bulgaria has been observed for a period of four days between 13 and 16 January 2019, in the vicinities of the town of Karlovo (CS Bulgaria). The bird was recorded and captured on 16 January 2019 on the territory of the $61^{\text {th }}$ Stryama Mechanized Brigade (a mechanised infantry brigade) in Karlovo. It was very exhausted and apparently suffered from the cold necrosis owing to the frosting of the toes of both legs. The bird was transferred alive to the Wildlife Rehabilitation and Breeding Centre - Green Balkans in the town of Stara Zagora (Figs 2, 3), where it died. The bird was ringed with a ring of the Rosegg Tierpark (Rosegg, Carinthia State, S Austria). The inscription of the ring is as follows: TR Rosegg AUT 0043.427452357 (Fig. 4). The Rosegg Tierpark is currently working on a LIFE+ project of the reintroduction of the bald ibis (2013-2019). As a result, "More than 120 northern bald ibises are to be migrating between the northern

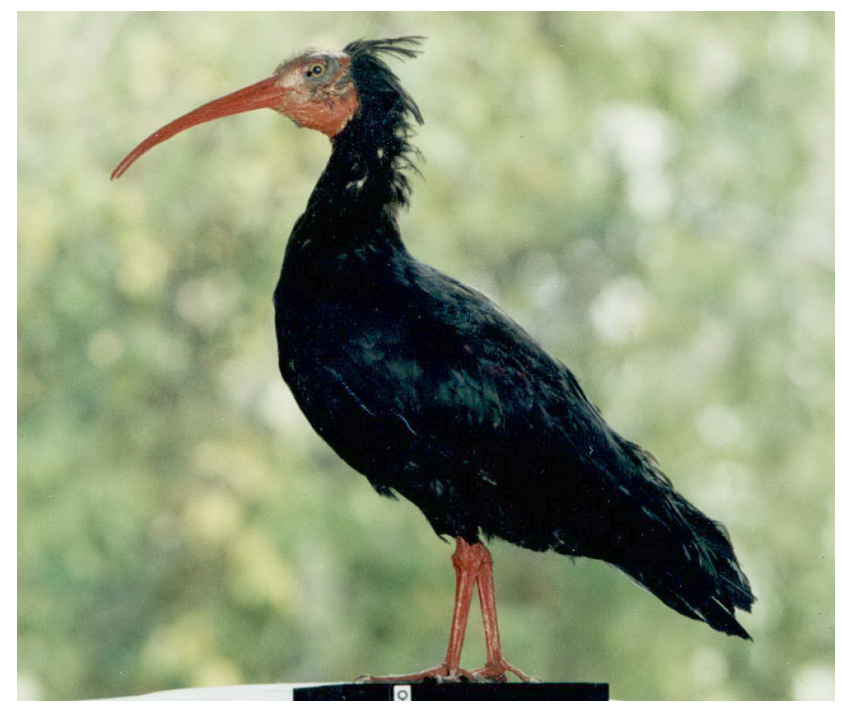

Fig. 1. Geronticus eremita, NMNHS 2148 ad, female. Photo: Georgi Tsonev.

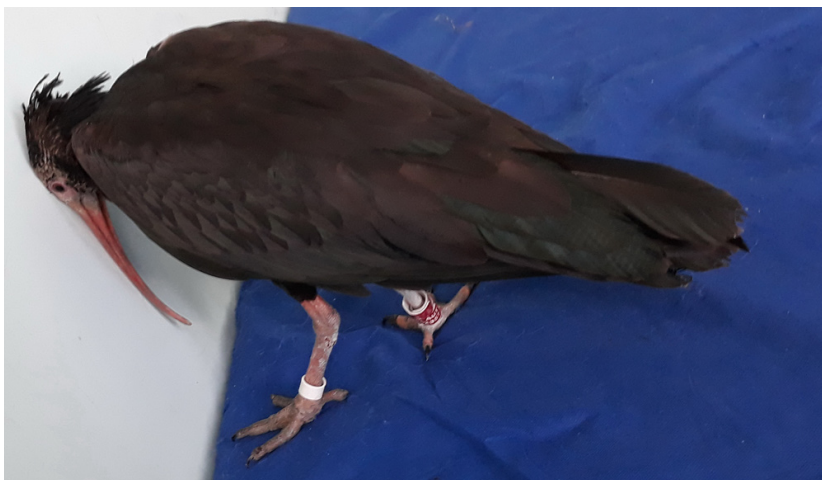

Fig. 2. Geronticus eremita, specimen from the $61^{\text {th }}$ Stryama Mechanized Brigade in Karlovo, Bulgaria. Photo: Gradimir Gradev.

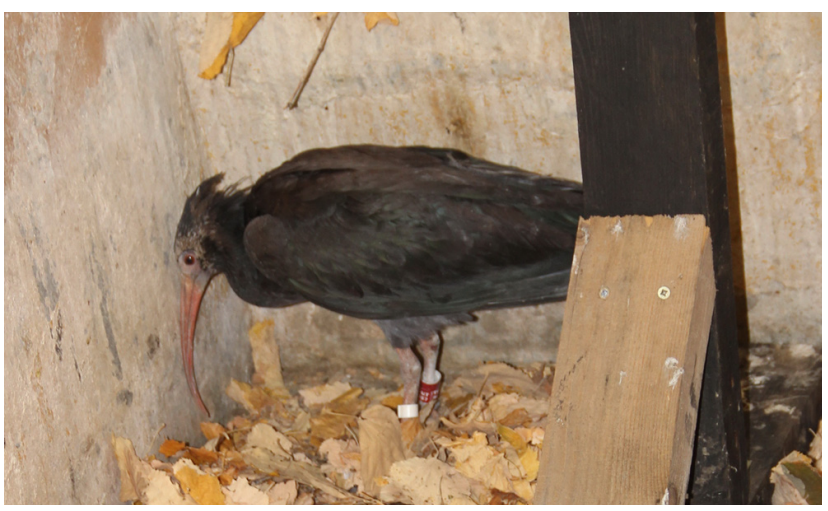

Fig. 3. Geronticus eremita, specimen from Karlovo in the Wildlife Rehabilitation and Breeding Centre in Stara Zagora, Bulgaria. Photo: Hristina Klisurova. 


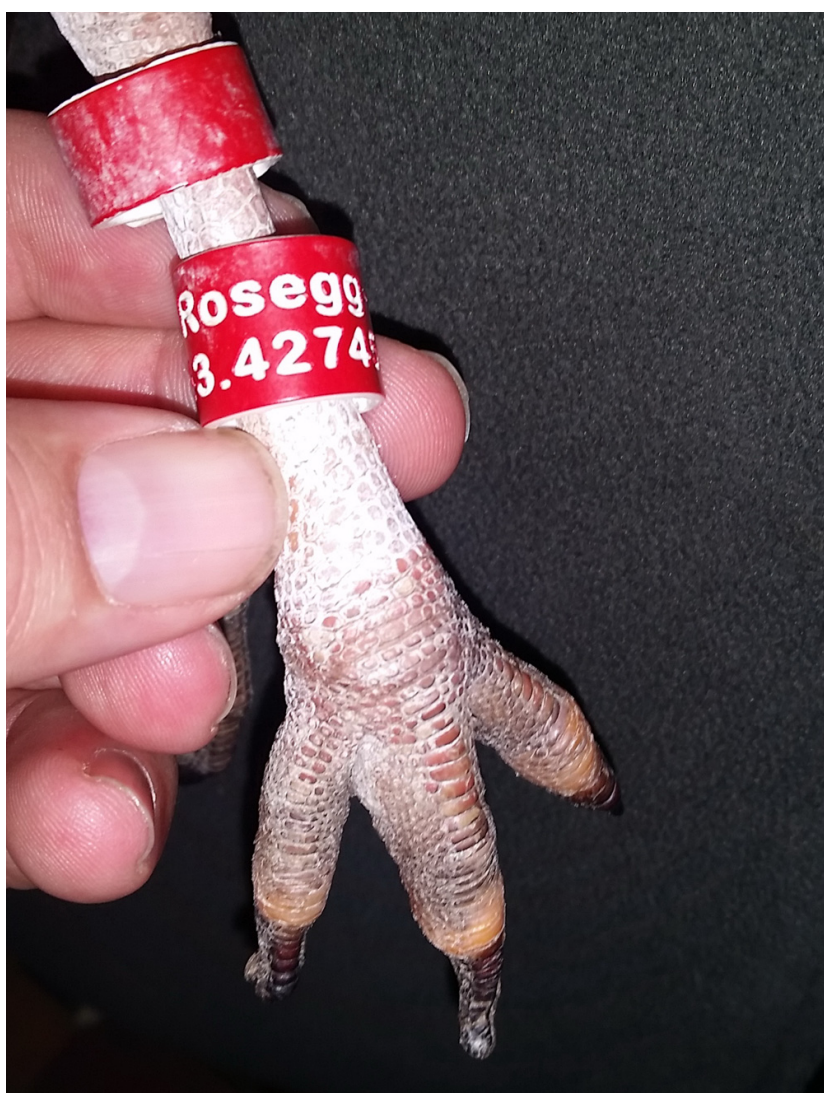

Fig. 4. Geronticus eremita, specimen from Karlovo, left leg with ring of the Rosseg Tierpark, Austria. Photo: Gradimir Gradev.

foothills of the Alps and the wintering area in Tuscany" (Anonym., 2019). Obviously, one of these birds has departed from his way and has been registered in Bulgaria.

\section{Discussion}

In the $2^{\text {nd }}$ decade of the $21^{\text {st }}$ century the northern bald ibis was still breeding in south-western Morocco, where the species was the subject of wide conservation measures (Fig. 5). There, in 2016 at least 111 breeding pairs were registered from two colonies (Aourir et al., 2017). Until the mid-1980s it bred in Algeria (del Hoyo \& Collar, 2014). The breeding population in the south-eastern Turkey got extinct by 1989. In addition, a relict breeding colony was discovered in Syria in 2002 but by 2013 it has almost died out completely. The eastern population migrates via the Arabian Peninsula to Central Ethiopia, where it winters (del Hoyo

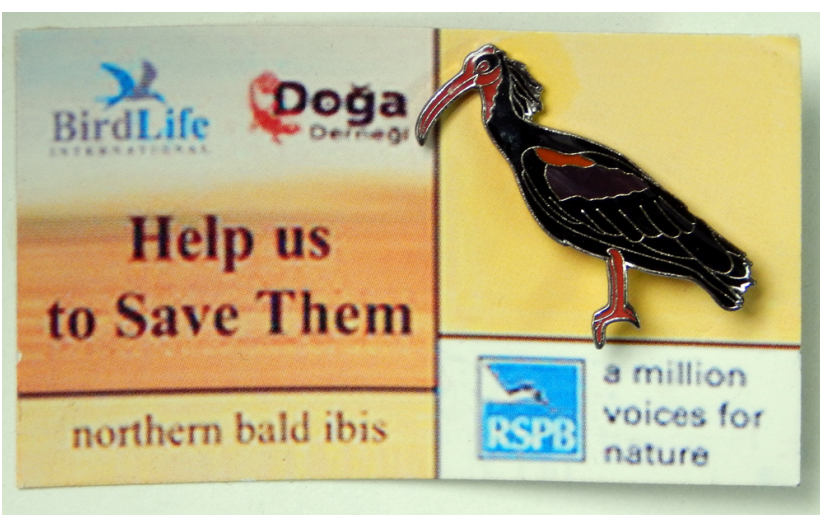

Fig. 5. A jewellery badge with an image of the northern bald ibis, promoting species conservation in Morocco. 2012; Photo: Z. Boev.

\& Collar, 2014). A semi-wild population and several captive populations are maintained in Austria and Spain. Birds from these populations were released in some parts of the former species' range in Europe (del Hoyo \& Collar, 2014).

The Austrian-German-Italian reintroduction project founded three breeding populations in Burghausen (Bavaria) and Überlingen (Baden-Württemberg) in Germany and in Kuchl (Salzburg) in Austria. As the reintroduced Central-European captive populations originate from the last survived native colonies in the Middle East (SE Turkey, NW Syria), it is plausible to explain the observation in Karlovo, being a place on the former migratory way of the former population that has been gradually reduced and retreating towards the south-east (from the Alps to Asia Minor).

\section{Conclusion}

Although being an escape specimen, the bald ibis from Karlovo originates from Central Europe and has been recorded in Bulgaria, ca. 1100-1400 km south-east of the point of its releasing. Here we provide valuable information on the migratory phenology of one of the rarest birds of the World.

\section{References}

Anonym. 2019 'Reason for Hope'. Reintroduction of the Northern Bald Ibis in Europe. http://waldrapp. eu/index.php/en/project (20 March 2019). 
Aourir M., Bousadik H., Bekkay M., Oubrou W., Znari M., Qninba A. 2017 New breeding sites of the critically endangered Bald Ibis Geronticus eremita on the Moroccan Atlantic Coast. Avian and Wildlife Biology 2 (3): 77-80.

BirdLife International 2018 Geronticus eremita. The IUCN Red List of Threatened Species 2018: e.T22697488A130895601. http:// dx.doi.org/10.2305/IUCN.UK.2018-2.RLTS. T22697488A130895601.en (20 January 2019).

Boev Z. 1992 Gorski ibis. Lov i ribolov 1: 12-13. (In Bulgarian)

Boev Z. 1998 Presence of Bald Ibises (Geronticus Wagler, 1832) (Threskiornithidae - Aves) in the Late Pliocene of Bulgaria. Geologica Balcanica 28 (1-2): 45-52.

Boev Z. 2000 Additional Material of Geronticus balcanicus Boev, 1998, and Precision of the Age of the Type Locality. Acta zoologica bulgarica 52 (2): 53-58.

Boev Z. 2003 Specimens of extinct and threatened birds in the collections of the National Museum of Natural History in Sofia, Bulgaria. In: Collar N., Fisher C., Feare Ch. (eds) Why Museums Mater; Avian Archives in Age of Extinction. Bulletin of the British Ornithologists' Club 123A. Suppl. 2003, 234-245.

Boev Z., Gerasimov G., Iankov P. 2007 Phasianus colchicus colchicus (Colchic) Pheasant. In: Iankov P. (ed.) 2007 Atlas of Breeding Birds in Bulgaria. Bulgarian Society of the Protection of Birds, Conservation Series, Book 10. BSPB. Sofia, 204-205.

del Hoyo J., Collar N. 2014 HBW and BirdLife International Illustrated Checklist of the Birds of the
World. Volume 1: Non-passerines. Lynx Edicions, Barcelona, 903 pp.

Desfayes M. 1987 Evidence for the ancient presence of the Bald Ibis Geronticus eremita in Greece. Bulletin of the British Ornithologists' Club 107 (3): 93-94.

Finlayson, C. 2011 Avian survivors. The history and biogeography of Palearctic birds. T \& AD Poyser. London, $304 \mathrm{pp}$.

Gretzer H. 1907 Collection ornithologique. In: Collections du Museé d'Histoire Naturelle de Son Altesse Royale, Ferdinand I, Prince de Bulgarie. Imprimerie de l'Etat, Sofia, 25-245.

Harrison C. 1982 An atlas of the Birds of the Western Palaearctic. Princeton University Press, New Jersey, $322 \mathrm{pp}$.

Mourer-Chauviré C., Philippe M., Guillard S., Meyssonnier M. 2006 Presence of the northern bald ibis Geronticus eremita (L.) during the Holocene in the Ardèche valley, southern France. Ibis 148: 820-823.

Perco F., Tout P. 2001 Notes on recent discoveries regarding the presence of the Northern Bald Ibis Geronticus eremita in the Upper Adriatic Region. Acrocephalus 22 (106-107): 81-87.

Schwägerl Ch. 2018 After a 400-Year Absence, A Rare Ibis Returns to European Skies. https:// e360.yale.edu/features/after-a-400-year-absencewaldrapp-rare-ibis-returns-to-european-skies (20 March 2019).

Tyrberg T. 1998 Pleistocene birds of the Palearctic: a catalogue. Publications of the Nuttall Ornithological Club, No 27, Cambridge, Massatchusetts, $720 \mathrm{pp}$. 